\title{
Application of Management Control System in Nepalese Commercial Banks
}

\author{
Saroj Rijal
}

\begin{abstract}
This paper attempts to examine the application of management control system in Nepalese commercial banks. The Nepalese commercial banking sector is very competitive. The commercial banks are competing mainly in service and many of them adapting differentiation strategy. The priority of the majority of commercial banks is customer retention. Commercial banks are encouraging employees to upgrade their knowledge and skill. The working environment is also congenial in Nepalese commercial banks and the informal organization and communication system also gradually exist in some of the commercial banks of Nepal. However, the future research needs to examine the relationship between management control system and effectiveness of the commercial banks of Nepal.
\end{abstract}

Key words: commercial bank, management control system

IN NEPAL, DURING 1990S AND later many organizations faced major changes in competitive business environment. Before 1990s organizations such as those operating in the airlines, utilities, and financial sectors were either government owned monopolies or operated in a highly regulated and non-competitive environment. These organizations were not subject to any great pressure to improve the quality and efficiency of their operations or by eliminating services that were making losses. Some public enterprises were getting direct subsidies from government for equalizing their operational losses.

Privatization of some of the government owned enterprises and deregulation in early 1990s changed the competitive environment in Nepalese business environment. Large number of joint venture commercial banks and development banks were established and the process is being continued.

Commercial banks play significant role in the economic development in the nation. In Nepal 19 commercial banks are in operation and providing services to the business and industries through long-term and short-term loans and facilitating business for foreign exchange and remittance via national and international network.

The development of banking system in Nepal was emerged after the liberalization and free market concept. In the beginning of 1980s, private commercial banks came into operation in collaboration with foreign banks. It took pace after 1990s and number of financial institutions has been increased. All the newly established commercial banks tired to operate efficiently and effectively resulting high competition in Nepalese banking industry. In this connection, the service operation of commercial banks has become more important for the number of reasons:

- Competition in financial markets has intensified with the entry of new joint venture and domestic banks, and other financial intermediaries.

- The cost of operating the bank branches has been increased with the need of better quality service.

- Increased in Non Performing Assets and 
- Increased in liquidity position

Today and more precisely in future, companies, organizations and other decision making entities whether profit making or not, will face major management challenges. Irrespective of whether the main goal of the organization is to make profit or not, it becomes necessary to institute a mechanism in those entities to control the activities of managers so that they remain on track of the proper routes as established by management. In order to keep activities of the organization in track a management control system is essential.

Control in the broad sense of the term relates both organizational structure (Chandler 1962) and informal process (Cyert and March 1963). Management control system a logical integration of techniques to gather and use information to make planning and control decision, to motivate employees behavior, and to evaluate performance (Horngren, Sundem and Stratton 2002). It is the process by which managers assure that resources are used effectively and efficiently in the accomplishment of the organization's objectives' - in other words control using both financial and non-financial objectives. It is specifically concerned with the process by which managers influence other members of the organization to implement the organizational strategies (Govindarajan and Anthony 2001). It involves number of activities:

- Planning what the organization should do

- Coordinating the activities of several parts of the organization

- Communicating information

- Evaluating information

In coping with the competitive forces, there are three potentially successful generic strategic approaches to outperforming other firms in an industry; overall cost leadership, differentiation and focus (Porter 1998).

A control system is a set of formal and informal systems that designed to asset management in steering the organization towards the achievement of its purpose by bringing unity out of the diverse efforts of subunits and individuals (Marciallo and Kirby 1994). The formal system and informal system are independent but they are highly interrelated, indistinguishable, subdivision of control system.

Formal system makes possible the delegation of authority. Formal documentation of structure, policies, and procedures assist members of the organization in performing their duties (Wu 2003). An effective set of formal control includes three major mechanism-operational plans, performance measurement systems, and feedback mechanism (Stewart, 2002) Operational plans: Operational plans include the firm's annual master budget and related supporting work plans. They provide the linkage between senior management's strategic plans and the day-to-day organizational activities of each employee.

Performance Measurement: Performance measurement systems compile and report the result of the collective work activities on periodic basis. An effective performance measurement system presents both financial results and operating data on a responsibility basis.

Feedback Mechanism: Feedback mechanism reports the variances between actual and planned performance. The variance is communicated to mangers and others within the organization periodically through various interim reports. Informal system requires management a mindset that differs from that required for formal controls. "Informally" refers to the flexibility to deal with any action beyond the documentary discipline and regulation. In this 
respect formally leads to a pattern of defined behaviors whereas informally leads to a pattern of interacting roles between two systems (Marciall and Kirby 1994). The informal control system consists of five components:

Informal Control Process: Under certain conditions and uncertainty, management will try to gather more and accurate information from the dynamic environment and adapt organizational goal. All these goal-directed actions are based on the experience and skill of management.

Infrastructure: Infrastructure includes personal contacts and network. A personal contact is a model of communication within the organization that acts an efficient method to exchange ideas and information between different levels of the organization

Management Style and Culture: Management and culture represent the dominant way that the top management and whole organization have chosen to conduct their work.

Informal Rewards: Informal rewards are status oriented. Individual employees are rewarded not only in financial terms. The informal rewards are important because it encourages employees to carryout their job efficiently

Coordination and Integration: Coordination and integration is considered as interpersonal relationship, which can be changed and adapted to meet the needs of the organization members. Informal communication helps deeper discussion of sensitive issues in a softer and flexible environment.

The reward system is not so much the money; it is also the friendship and working relationship (Wo 2003). The quality of work life is having work environment where an employee's activities become more important (DeCenzo and Robbins 1996). It means implementing procedure that makes the work less routine and more rewarding for the employees. These procedures include autonomy, recognition, belongingness, progress and development, and external rewards.

The importance of management control system has been increased significantly in recent years (Kald, Nilson \& Rapp 2002). One indication of this growing importance is the impact of balance scorecard. The balance scorecard is a management system (not only measurement system) that enables organization to clarify their vision and strategy and translate them into action. The balance scorecard suggests that management views the organization from four perspectives, and to develop metrics, collect data and analyze it relative to each of these perspectives:

1. The learning and growth perspective

2. The business process perspective

3. The customer perspective and

4. Financial perspective

The four perspective of the scorecard permit a balance between

- Short term and long term objectives

- External measures for shareholders and customers and internal measures of critical business process, innovation, and learning and growth

- Outcomes designed and the performance drives of those outcomes

- Hard objectives measures and softer, more subjective measures

In recent years a new financial theory-Economic Value Added (EVA) has been developed for the measurement of financial performance of a company (Stern Stewart 1993). 
EVA is both a measure of value and also measure of performance. The value of a business depends on investor's expectation about the future profits of the enterprise. Stock prices track EVA far more closely than they track earning per share or return on equity. A sustained increase in EVA will bring an increase in the market value of the company. EVA is changing the way managers run their business. When business decisions are aligned with the interest of the shareholders, it is only a matter of time before these efforts are reflected in a higher stock price (Durant Micheal 1998).

\section{Problem Identification}

Banking industry is high-risk business but not necessarily high profit industry. It is quite difficult to manage risk and return in banking industry. The internal management system in some of the commercial banks of Nepal is inebriated from traditional management system of government. The pyramid shape organizational structure of some banks caused adverse effect in their business development.

In any institution human resources, which is not listed in balance sheet but very important intangible assets? Modern economy entered into information age. Competitive business environment in banking industry also caused lateral movement of human resources. The traditional management theory could not completely fit the operational environment in banking business in Nepal. In this context, this paper attempts to find some hints from the well-developed theory to get some new ideas. To sum up, the major issues discussed in this paper are as follows:

- Competitive situation in Nepalese banking sector

- What kind of management control system do the Nepalese commercial banks apply?

- How the performance is evaluated?

- What reward system the commercial banks have been adopting?

- How commercial banks are encouraging their employees to learn new skill and knowledge?

\section{Data and Methodology}

The paper is based on both primary and secondary data. Primary data have been collected from the structured questionnaire developed for branch manager and employees of different commercial banks at different branches. The responses were received from the 26 managers and 76 supporting employees of 13 commercial banks. Secondary data have been collected from the website of Nepal Stock Exchange Limited, Nepal Rastra Bank, and concerned commercial banks. The data, collected from various source have been analyzed using statistical tools and with the support of previously developed theory.

\section{Results}

Competitive Environment in Nepalese Commercial Banking Sector: The degree of competition in Nepalese commercial banking sector is very high. The majority (76.9 percent) managers of the branches of the commercial banks of Nepal feel intense competition. The commercial banks of Nepal are competing mainly on service followed by the cost and other factors respectively. 
Generic Strategy of Nepalese Commercial Banks: The generic strategy of Nepalese commercial banks has been divided for two main areas of business: deposit and lending. The different branches of the same commercial banks at the different geographical location are adapting different strategy. Around fifty two percent branches of commercial banks are concentrating on differentiation strategy and 47.4 percent are following focus strategy to attract the depositors. In case of lending, majority of branches (52.6 percent) of such banks are adapting differentiation strategy followed by focus (42.1 percent) and cost leadership (5.3 percent).

Services Offered by Nepalese Commercial Banks: Nepalese commercial banks have been offering number of services to their customers. The services are ranging from 3 to more than 25 . The majority of such branches of commercial banks (42.3 percent) are offering more than 21 products. Similarly, 15.4 percent and 30.8 percent of such braches of commercial banks are offering 16-20 and 5-10 services respectively. Only few (11.5 percent) are offering 1-5 services to their customers. In order to compete in highly competitive environment, these banks are continuously introducing new services through their branches established at different places in the country. Majority (76.9 percent) of such commercial banks are introducing 3-4 services every year, and only 11.5 percent of such braches of the commercial banks are offering 5-6 and 6-7 services every year.

Marketing of New Services: Twenty-three percent branches of the commercial banks of Nepal promote their products/service very aggressively. Similarly, 30.8 percent and 46.2 percent branches promote/advertise their new services aggressively and normally respectively. The majority of the commercial banks branches are concentrating in maintaining (retaining) customers and only 28 percent of such branches are competing for customer acquisition.

Target Setting Practice: All the commercial banks of Nepal set target for their branches for the purpose of planning and controlling the activities. In majority (96.2 percent) of the branches the target is fixed in terms of number of clients, amount of deposit, and the amount of lending. Only in few (3.8 percent) braches the target is fixed in other terms. Concerning to individual level, $83.3 \%$ employees responded their banks set target for them and only $16.7 \%$ responded they don't get any target for their performance. Out of the individuals who think their bank set target for them, $95.4 \%$ feel the target is clearly communicated to them and only $4.6 \%$ feel that the target is not clearly communicated to them.

Performance Measurement: All commercial banks compare actual performance with predetermined target of their braches frequently. Coming to the individual level, 65.4 percent respondents feel their actual performance is compared with predetermined target and remaining do not know whether their actual performance is compared with standard or not. The managers of different commercial banks still desire to evaluate the performance of their banks and branches on the basis of net profit margin (Table 1). After net profit margin they tend to support ROE, ROI, EVA and others (including the degree of NPA) respectively. 
Application of Management Control System in Nepalese Commercial Banks

Table 1: Performance Evaluation Criteria in Nepalese Commercial Banks

\begin{tabular}{lccccccccc}
\hline Criteria & 1 & 2 & 3 & 4 & 5 & Total & $\begin{array}{c}\text { Weight } \\
\text { Value }\end{array}$ & $\begin{array}{c}\text { Mean } \\
\text { Value }\end{array}$ & Rank \\
\hline Return on Investment & 4 & 3 & 2 & 4 & 0 & 13 & 32 & 2.46 & 3 \\
Net Profit Margin & 4 & 5 & 2 & 2 & 0 & 13 & 28 & 2.15 & 1 \\
Return on Equity & 2 & 4 & 7 & 0 & 0 & 13 & 31 & 2.38 & 2 \\
Economic Value Added & 3 & 1 & 2 & 7 & 0 & 13 & 39 & 3.00 & 4 \\
Others & 0 & 0 & 0 & 0 & 0 & 13 & 65 & 5.00 & 5 \\
\hline
\end{tabular}

Reward System: Employees in any organization work for reward, and most important reward is money, but individual expect more than wages or salary from their employees (DeCenzo and Robbins 1988). In Nepalese commercial banking sector, salary/benefit/promotion is mostly determined by performance followed by education, experience, relationship, and other factors respectively.

Table 2: Employees Response to Factors Affecting Salary and Benefit

\begin{tabular}{lccccccccc}
\hline Criteria & 1 & 2 & 3 & 4 & 5 & Total & $\begin{array}{c}\text { Weight } \\
\text { Value }\end{array}$ & $\begin{array}{c}\text { Mean } \\
\text { Value }\end{array}$ & Rank \\
\hline Performance & 30 & 6 & 1 & 0 & 2 & 39 & 55 & 1.41 & 1 \\
Experience & 3 & 15 & 19 & 2 & 0 & 39 & 98 & 2.51 & 3 \\
Relation & 0 & 2 & 3 & 17 & 17 & 39 & 166 & 4.26 & 4 \\
Education and Training & 4 & 16 & 15 & 4 & 0 & 39 & 97 & 2.49 & 2 \\
Others & 2 & 0 & 1 & 16 & 20 & 39 & 169 & 4.33 & 5 \\
\hline & 39 & 39 & 39 & 39 & 39 & & & & \\
\hline
\end{tabular}

Regarding additional benefit for better performance (performance higher than the standard), 53.8 percent responded they get additional benefit for better performance. Seventeen percent respondents say they don't get any additional benefit for better performance and 28.2 percent did not provide any comment on this dimension.

Majority of commercial banks are providing bonus to their employees out of profit. The amount of bonus is based on the amount of salary the employees are getting. It indicates that the bonus is not based on the outstanding performance of an employee or a group of employees.

Encouragement to employees to learn new skills: At present all commercial banks are encouraging their employees to discharge better performance and enhance educational qualification and attain trainings. It is supported by the response provided by managers and employees of such commercial banks in Table 3 and Table 4 respectively.

Table 3: Managers Response Relating to Factors Affecting Employees Benefit and Compensation

\begin{tabular}{lccccccccc}
\hline Criteria & 1 & 2 & 3 & 4 & 5 & Total & $\begin{array}{c}\text { Weight } \\
\text { Value }\end{array}$ & $\begin{array}{c}\text { Mean } \\
\text { Value }\end{array}$ & Rank \\
\hline Number of Years in Job & 3 & 4 & 5 & 0 & 4 & 16 & 46 & 2.88 & 3 \\
Training Related to Job & 0 & 0 & 7 & 9 & 0 & 16 & 57 & 3.56 & 4
\end{tabular}


The Journal of Nepalese Business Studies

\begin{tabular}{lccccccccc}
\hline Educational Qualification & 4 & 5 & 4 & 3 & 0 & 16 & 38 & 2.38 & 2 \\
Performance & 9 & 7 & 0 & 0 & 0 & 16 & 23 & 1.44 & 1 \\
Relationship & 0 & 0 & 0 & 4 & 12 & 16 & 76 & 4.75 & 5 \\
\hline
\end{tabular}

Table 4

Employees Response Relating to Factors Affecting Employees Benefit and Compensation

\begin{tabular}{lccccccccc}
\hline Criteria & 1 & 2 & 3 & 4 & 5 & Total & $\begin{array}{c}\text { Weight } \\
\text { Value }\end{array}$ & $\begin{array}{c}\text { Mean } \\
\text { Value }\end{array}$ & Rank \\
\hline Performance & 30 & 6 & 1 & 0 & 2 & 39 & 55 & 1.41 & 1 \\
Experience & 3 & 15 & 19 & 2 & 0 & 39 & 98 & 2.51 & 3 \\
Relation & 0 & 2 & 3 & 17 & 17 & 39 & 166 & 4.26 & 4 \\
Education and Training & 4 & 16 & 15 & 4 & 0 & 39 & 97 & 2.49 & 2 \\
Others & 2 & 0 & 1 & 16 & 20 & 39 & 169 & 4.33 & 5 \\
\hline
\end{tabular}

The majority of employees (77.3 percent) working in Nepalese commercial banks responded that they generally get leave/deputation sanctioned from their bank to attain training related to their job. It also supports that the commercial banks are encouraging employees to learn new skill and knowledge.

Cooperation and Communication: Majority of the employees (96.2 percent) working in Nepalese commercial banks feel they get complete cooperation from their coworkers. It indicates the working environment is very conducive in Nepalese commercial banks to discharge better performance. The majority of Nepalese commercial banks are organizing some sort of recreational activities for their employees. Those who responded that their bank organize recreational activities, 71 percent says they talk about the official job during the time with the executive/boss other than their immediate supervisor. It indicates employees use informal organization/time to communicate the official matter with their seniors.

\section{Conclusion}

The Nepalese commercial banking sector is very competitive. The commercial banks are competing mainly in service in order to put in competitive position, majority of the branches of commercial banks have been adapting differentiation strategy. The response shows that different branches of the similar bank have adapted different strategy and few of the banks have followed more than one strategy at the same time.

Majority of commercial banks are offering more than 21 services to their customers through different branches established at different geographical location. Most of the commercial banks (76.9 percent) are introducing 3-4 services in a year. When new services are offered 53.8 percent of them promote aggressively. The priority of the majority of Nepalese commercial banks is to retain customers whereas 28 percent of them are concentrating on customer acquisition.

All the commercial banks are applying the concept of management control system by setting target for their branch and at individual and comparing it with actual performance. The target for a branch is fixed in terms of number of clients, amount of deposit and lending. Target is also fixed for the majority of the individuals. Around eighty-three percent 
employees responded that they get target for their performance and it is clearly communicated to them. The target of branches and individual level is frequently monitored. The manager of the different branches of the different commercial banks desire to evaluate the performance of the branch on the basis of traditional tools like NIM, ROE, and ROI.

Regarding individual level, 65.4 percent employees, of those commercial banks think that their performance compared with predetermined standard. Around eighteen percent employees do not know whether their performance is evaluated or not, and 3.8 percent responded feel their performance is not compared with the standard. According to employees' response, their financial and non financial benefit is based on performance followed by education and training and experience respectively. But the yearly bonus is based on the percentage of salary they are getting. 53.8 percent employees responded that they are paid higher for higher performance, compared to predetermined standard.

All the managers of different branches of different commercial banks encourage employees to participate in decision-making process. But, according to employees, it is not clearly communicated to them. Commercial banks of Nepal are encouraging employees to upgrade their knowledge and skill as the benefit is based on educational qualification and training after performance, they provide paid leave to participate in training and for further education.

The working environment in Nepalese commercial banks is very congenial as the majority of the respondents ( 75 percent) felt that they get very much cooperation from their coworkers. The existence of informal organization and informal communication system are there in some of the commercial banks. However, the future research needs to examine the relationship between management control system and effectiveness of the commercial banks of Nepal.

\section{REFERENCES}

Anthony, Robert N. and Govindarajan Vijaya. 2002. Management Control System. Delhi: Tata McGraw-Hill. Chandler, A.D. 1962. Strategy and Structure: Chapters in The History of The Industrial Enterprise. New York: Anchor Books.

Cyrt, R.M. and March J.G. 1963. A Behavioral Theory of The Firm. Englewood Cliffs: Prentice Hall.

DeCenzo, D.A. and Robbins S.P. 1988. Personnel/Human Resource Management. New Delhi: Prentice Hall of India.

Durant Micheal. 1998. The Invisible Hand at Work. Columbia, USA: Credit Research Foundation.

Horngren, C.T., Sundem, G.L., \& Stratton, W.O. 2002. Introduction to Management Accounting. Delhi: Pearson Education.

Kald, Magnus, Nilson, Fredric, \& Rapp, Birger. 2000. On Strategy and Management Control: The Importance of Classifying the Strategy of the Business. British Journal of Management 11: 197-212.

Marciarielo, J.A. \& Kirby, C.J. 1994. Management Control System: Using Adaptive System to Attain Control. Englewood Cliffs: Prentice Hall.

Porter, M.E.1980. Competitive Strategy: Techniques for Analyzing Industries and Competitors. New York: Free Press.

Stern, Stewart. 1993. EVA-The Real Key to Creating Wealth. Fortune Magazine: 20.

Wu, Xianoxian. 2003. "Application of Management Control System: Case of CCB." Masters diss., Maastricht School of Management. 